\title{
THE BRAZILIAN EOGONDWANIC FLORAL SUCCESSION
}

\section{OSCAR RÖSLER}

Departamento de Paleontologia e Estratigrafia

This paper has the objective to present an actualized scheme of the distribution of fossil plant assemblages in the outcroping sediments of the Paraná Basin (Brazil). Based on this scheme some general aspects, including the problem of the Carboniferous-Permian boundary, are briefly discussed.

A review of such distribution was pre- 
sented by RIGBY (1970), suggesting the possibility to recognize two floras, calling the flora of Tubarão Group the "Glossopteris-Gangamopteris Flora", and the flora of Passa Dois Group the "Lycopodiopsis Flora". RÖSLER (1973) distinguished four groups of fossil plant assemblages (= Taphofloras) named by letters $A$ (older) ito $D$ (younger). An younger taphoflora $(E)$ was discoverd thereafter in the Uppermost Permian (RösLER, 1975a, 1975b \& in press).

The present paper is a synopsis and brings this subdivision up to date. It is mainly based on the result of an extensive sistematic field work during which tens of new fossil plant localities were discovered, some of them very important to this study, like S. J. Triunfo (1 RB/PR), Fluviópolis (86 EN/PR) and Dorizon (79 RR/PR) (Fig. 1).

All samples collected during the field work programme refered here are in the Palaeobotanical Collection of the Departament of Palaeontology and Stratigraphy, Institute of Geoscience, University of São Paulo (Brazil).

Six fossil plant assemblages (taphofloras) were recognized (Fig. 2):

Taphoflora A - Characterized by: Paracala mites, Paranoclodus, Lycopodiopsis pedroanus and Samaropsis as common elements. Presence of Botrychiopsis, Noeggerathiopsis, Buriadia, etc. Absence, at least apparently, of Gangamopteris and Glossopteris. Occurrence: Itararé Subgroup, Monte Mor Locality (4 IT/SP), São Paulo State. It is the oldest taphoflora of the studied sequence. Probable age: Stephanian.

Taphoflora B - Characteristics: Asterotheca, Pecopteris spp. and Annularia are abundant. Relatively common elements are:Paranoclodus, Lycopodiopsis pedroanus, Paracalamites, Gangamopteris, Glossopteris, Sphenophyllum, etc. Occurrence: Basal to middle part of the Rio Bonito Formation, mainly at localities of Northeast and South of Parana State. Typical locality: São João do Triunfo (1 RB/PR). Age: Lower Permian.

Taphoflora C - Characteristics: Glossopteris and Gangamopteris are abundant Relatively common elements are: Arberia Noeggerathiopsis, Rhodiopteridium, and many others according to the localities. Lycopodiopsis is not common and ferns are rare. Annularia has not been recorded. Occurrence: Mainly in the upper, but some in the middle part of Rio Bonito Formation, in the North and South of Santa Catarina State. Typical locality: Criciuma, S. Catarina (21 RB/SC). Probable age: Artinskian to Kungurian.

Taphoflora D - Characteristcs: Presence of Lycopodiopsis derbyi as one of the most common elements. Some localities have yelded Krauselcladus (Yoshida, 1970), Ginkgophyte leaves, and Charophyte remains. Absence of several characteristic forms of the taphofloras A, B and C. Taphoflora D could be called a "taphofloristic complex". Occurrence: Irati Formation with an informal Polysolemoxylon zone) and mainly Estrada Nova Formation, from São Paulo to Rio Grande do Sul. Typical localities: Artemis (3 EN/SP), Laras (7 EN/SP) and Fluviopolis (86 EN/PR). Age: Upper Permian.

Taphoflora E - Characteristics: This taphoflora contains the last (youngest) occurrences of Glossopterids. They are represented by some few species of Glossopteris, generally small and particularly narrow leaves. Sphenophyllum are of the Sph. speciosum type. Other elements are considerably less common, but it is important to quote the presence of ?Dizeugotheca sp. Occurrence: Rio do Rasto Formation in Paraná and Santa Catarina. Typical locality: Dorizon, Parana (79 RR/PR). Age: Upper Permian to? Lower Triassic.

Taphoflora F - Characteristics: Several of Dicroidium and other elements of Triassic age. Absence of the characteristic elements of the preceeding taphofloras. Occurrence: Santa Maria “facies" (Rosario do Sul Formation, Rio Grande do Sul (75 SM/RS, etc.). Age: Middle Triassic.

Some localities like Cerquilho Velho (38 IT/SP) and Acampamento Velho (33 TU/RS) seem to represent the first occurrences of Glossopteridis. Untill further studies I am considering them as intermediary (or Transi- 


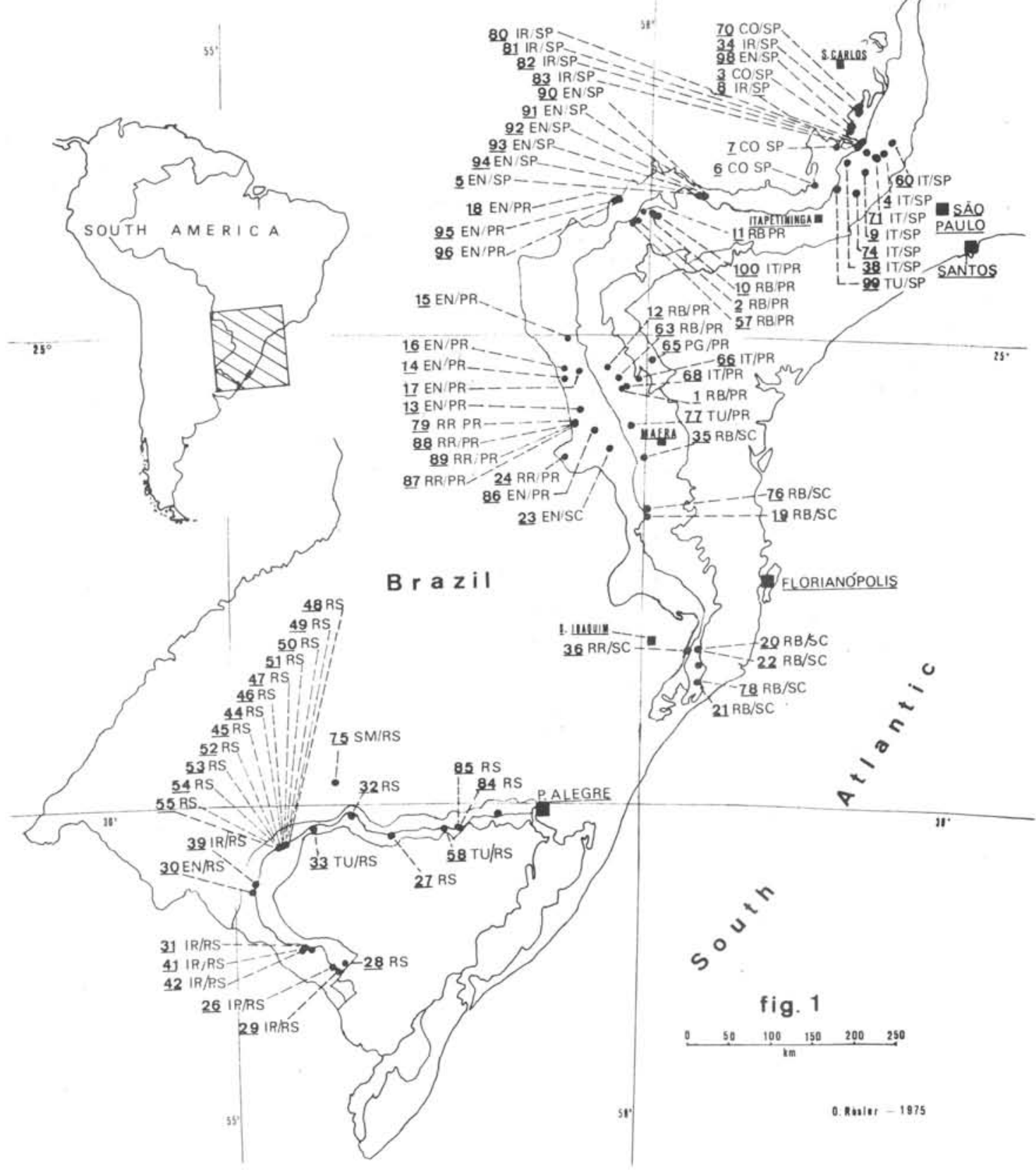

FIG. 1

Eastern area of outcroping sediments of the Paraná Basin, showing the relative situation of the localities refered in the text and fig. 2 .

Major stratigraphic and geographic situation of each locality is indicated by the letters:

Lithostratigraphic units:

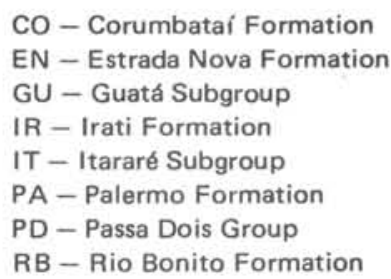

$$
\begin{aligned}
& \text { RO - Rosário do Sul Formation } \\
& \text { RR - Rio do Rasto Formation } \\
& \text { SM - Santa Maria Formation } \\
& \text { TU - Tubarão Group }
\end{aligned}
$$

Geographic names:

$$
\begin{aligned}
& \text { PR - State of Paraná } \\
& \text { RS - State of Rio Grande do Sul } \\
& \text { SC - State of Santa Catarina } \\
& \text { SP - State of São Paulo }
\end{aligned}
$$


tional) between taphofloras A and B. Those localities contain mainly "gangamopteroids" leaves. Thus, the oldest rest of Glossopterids found during this study are those of the uppermost part of the Itararé Subgroup bellow the last recorded (youngest) diamictites.

The first (oldest) abundant and clearly distinguished Glossopteris species in the lowermost part of the Rio Bonito Formation in several localities. The predominance of Glossopteridales in the assemblages is observed in the middle and upper part of the Rio Bonito Formation, mainly in Santa Catarina and Paraná States. Their younger occurrence is in the Rio do Rasto Formation. So, the lower limit of
Glossopteris in this area coincides with the probable transition to post glacial conditions and its upper limit coincides with increasingly arid conditions. The actual record suggests that Gangamopteris appeared before Glossopteris.

There are several causes that could be pointed as responsible for the differences and similarities among these fossil plant assemblages. Obviously some of the differences and similarities are clearly caused by local conditions of deposition. This is mainly true for Taphoflora $D$, where assemblage composition varies considerably from one

\begin{tabular}{|c|c|c|c|c|c|c|c|c|c|c|c|c|c|c|c|c|c|c|c|c|c|c|c|c|c|c|c|c|}
\hline \multirow{3}{*}{$\begin{array}{c}\text { TAPHOFLORAS } \\
\text { LITHOSTRATIGRAPHIC UNITS }\end{array}$} & \multicolumn{4}{|c|}{ A 'trans' } & \multicolumn{5}{|c|}{ B } & & & \multirow{2}{*}{\multicolumn{4}{|c|}{ c }} & \multicolumn{8}{|c|}{ D } & \multirow{2}{*}{\multicolumn{3}{|c|}{ E }} & \multirow{2}{*}{\multicolumn{2}{|c|}{\begin{tabular}{|l} 
F \\
S.Bto.
\end{tabular}}} \\
\hline & & & & \multirow{2}{*}{\multicolumn{7}{|c|}{$\begin{array}{l}\text { Tubarão Group } \\
\text { Guatá } \mathrm{S}_{\text {q. }}\end{array}$}} & \multirow{2}{*}{\multicolumn{5}{|c|}{ Rio Bonito Fm. }} & \multirow{2}{*}{\multicolumn{8}{|c|}{$\begin{array}{c}\text { Passa Dois Group } \\
\text { Estrada Nova Formation }\end{array}$}} & & & & & \\
\hline & \multicolumn{3}{|c|}{ Itararé } & & & & & & & & & & & & & & & & & & & & & \multicolumn{3}{|c|}{ R. Rasto Fm } & \multicolumn{2}{|c|}{ SMFM } \\
\hline $\begin{array}{c}\text { LOCALITES } \\
\text { RAEPRESENTATIVE } \\
\text { TAXA }\end{array}$ & $\begin{array}{l}\frac{\hat{े}}{\mathrm{E}} \\
\frac{\nabla}{\nabla}\end{array}$ & 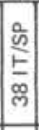 & 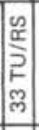 & 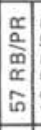 & 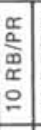 & 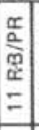 & 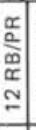 & $\begin{array}{l}\frac{\pi}{a} \\
\frac{a}{a} \\
\frac{\pi}{2} \\
\sim\end{array}$ & $\begin{array}{l}\frac{r}{a} \\
\frac{a}{a} \\
\frac{a}{a} \\
-\end{array}$ & 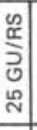 & 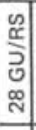 & \begin{tabular}{l|} 
\\
$\hat{\omega}$ \\
$\alpha$ \\
$\tilde{\alpha}$ \\
$\bar{\sim}$ \\
$\bar{v}$
\end{tabular} & 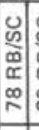 & 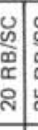 & 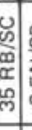 & 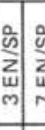 & $\begin{array}{l}\frac{\sigma}{\omega} \\
z_{w} \\
r\end{array}$ & \begin{tabular}{l|l}
$\frac{0}{w}$ & \\
$\sum_{u}$ & \\
$\varnothing$ &
\end{tabular} & 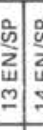 & 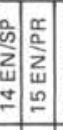 & $\begin{array}{l}\frac{\pi}{2} \\
2 \\
2 \\
w \\
=\end{array}$ & 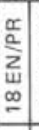 & 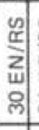 & 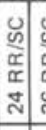 & 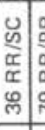 & 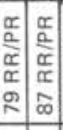 & 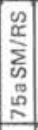 & 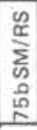 \\
\hline "Rhacopteris" (in Millan, 1972) & 今 & & & & & & & & & & & & & & & & & & & & & & & & & & & \\
\hline Botrychiopsis Kurtz & 0 & & & of & & & & & & & 아 & & & & & & & & & & & & & & & & & \\
\hline Paranocladus Florin & - & मे & & - & 이 & 이 & 占 & - & & & & & & & & & & & & & & & & & & & & \\
\hline Buriadia Seward and Sahni & 0 & & & of & & & 인 & 全 & & & of & 金 & & 이 & & & & & & & & & & & & & & \\
\hline $\begin{array}{l}\text { Lycopodiopsis pedroanus (Car- } \\
\text { ruthers) Edwards }\end{array}$ & 0 & & & 이 & 이 & 0 & 이 & $\bullet$ & 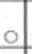 & 아 & 아 & & & & & & & & & & & & & & & & & \\
\hline Noeggerathiopsis Feistmantel & 0 & 它 & 이 & & & & 이 & & & 이 & 0 & 0 & 이 & & & & & & & & & & & & & & & \\
\hline Phyllotheca Brongniart & & 인 & & O & & & & 아 & 이 & 아 & & 0 & & 이 & & & & & & & & & & & & & & \\
\hline ?Gangamopteris McCoy & & 이 & 이 & & & & & & & & & & & & 全 & & & & & & & & & & & & & \\
\hline PGlossopteris Brongniart & & 金 & of & & & & & & & & & & & & & & & & & & & & & & & & & \\
\hline $\begin{array}{l}\text { Sphenophyllum brasiliensis } \\
\text { Rosler }\end{array}$ & & & & o & & & & 아 & & & & & & & & & & & & & & & & & & & & \\
\hline $\begin{array}{c}\text { Gangamopteris obovata (Car- } \\
\text { ruthers) White }\end{array}$ & & & & 이 & & & 이 & $\hat{z}$ & मे & 이 & & 0 & & 이 & मे & & & & & 出 & & & 合 & & & & & \\
\hline $\begin{array}{c}\text { Asterotheca cambuhyensis (Read) } \\
\text { Rosier }(\mathrm{m} / \mathrm{s})\end{array}$ & & & & 이 & & & 吕 & 이 & - & & & & & & & & & & & & & & & & & & & \\
\hline A. derbyi Rösler $(\mathrm{m} / \mathrm{s})$ & & & & & & & & 이 & - & & & & & & & & & & & & & & & & & & & \\
\hline Annularia Stenberg & & & & 이 & & & & 이 & - & & & & & & & & & & & & & & & & & & & \\
\hline $\begin{array}{r}\text { Gangamopteris buriadica var, } \\
\text { acrodeltoidis Dolianiti }\end{array}$ & & & & & & & & & & & & 0 & & & & & & & & & & & & & & & & \\
\hline $\begin{array}{c}\text { Glossopteris augustifolia } \\
\text { Brongniart }\end{array}$ & & & & & & & & & & & & 0 & & & & & & & st & 이이 0 & & & & & $\hat{A}$ & 의 & & \\
\hline $\begin{array}{l}\text { G. augustifolia var, taeniopteroi. } \\
\text { des viz, G. sewardii Plums. } \\
\text { tead }\end{array}$ & & & & & & & & & & & & 0 & & & & & & & & & & & & & & & & \\
\hline $\begin{array}{c}\text { Gangamopteris cylopteroides } \\
\text { Feistmantel }\end{array}$ & & & & & & & & & & & & 0 & & & & & & & & & & & & & & & & \\
\hline G. mosesi Dolianiti & & & & & & & & & & & & 0 & & & & & & & & & & & & & & & & \\
\hline Arberia White & & & & & & & & & & & & 0 & of & of & if & & & & & & & & & & & & & \\
\hline Rhodiopteridium Zimmermann & & & & & & & & & & & & 0 & 이 & & & & & & & & & & & & & & & \\
\hline Lycopodiopsis derby Renault & & & & & & & & & & & & & & & & - & - & 이 & & & 이 & & 이 & & & & & \\
\hline L. dolianiti Kräusel & & & & & & & & & & & & & & & & & 이 & & & & & & 이 & & & & & \\
\hline $\begin{array}{l}\text { PAsterotheca spp. (including? A. } \\
\text { ferruglioi, in Rigby, 1968) }\end{array}$ & & & & & & & & & & & & & & & & & 이 & & & & & & & & 아 & 이이 & & \\
\hline $\begin{array}{l}\text { Pecopteris spp. (including } P \text {. pa- } \\
\text { ranaensis, in Rigby, 1968) }\end{array}$ & & & & & & & & & & & & & & & & & 0 & & 의 & & & 이 & & & 아 & 이의 & & \\
\hline Thallites (in Rigby 1968,1970 ) & & & & & & & & & & & & & & & & & 인 & & & 임 & & & & & & & & \\
\hline Glossopteris sp. & & & & & & & & & & & & & & & & & & & & & & & & 의 & 이 & - 0 & & \\
\hline Sphenophyllum of. speciosum & & & & & & & & & & & & & & & & & & & & & & & & of & स. & 00 & & \\
\hline Dicroidium Flora spp. & & & & & & & & & & & & & & & & & & & & & & & & & & & $\bullet$ & $\bullet$ \\
\hline
\end{tabular}

FIG. 2

Distribution of some representative taxa in the main localites arranged in stratigraphic order. Localily notation as in fig. 1. 


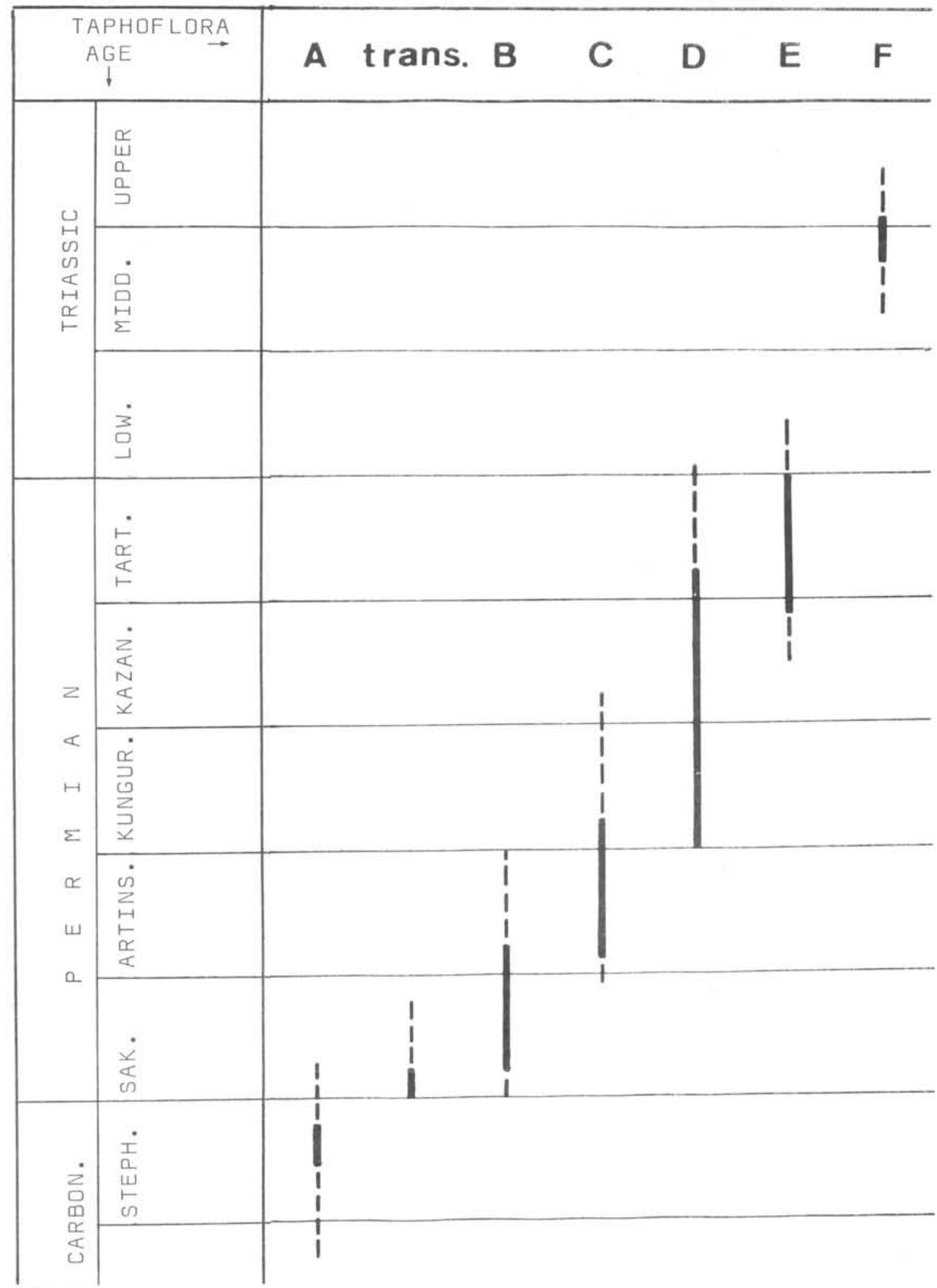

FIG - 3

Probable age ranges (solid lines) and possible age range (dashed lines) of the taphofloras dealt with in this paper. 
outcrop to another, though there are similarities in the composition among some of them with similar lithology. That is why taphoflora D has been refered as a "taphoflorist complex" which stratigraphic position is above Taphofloras $A, B$ and $C$, and bellow E.

Taphofloras $A, B$ and $C$ are mainly associated with the coal bearing strata. Some of their characteristics are due to "taphogenic causes" (KRASSILOV, 1969), but at least some others almost certainly reflect part of the original floral compositions. Taking the latter aspects into consideration, Taphoflora $A$ would represent a Pre-Glossopteris Flora; Taphoflora $B$ would represent a Glossopteris Flora mixed with "northern" forms, and Taphoflora $C$ would represent a "pure" Glossopteris flora. The same aspects also suggest some significant "subprovincial" differenciations across the studied region, but it is still very difficult to propose any phytogeographic unit.
Correlation of these taphofloras, based on their stratigraphic situation, on palynological studies and on the fossil plants themselves shows that Taphoflora $C$, is, at least in part, younger than $B$, and $B$, is younger than $A$ (Fig. 3 ).

There is at present insufficient basis for a definitive assignement of ages to the succession dealt with here, in terms of the internationally recognized geological time table. The ages here refered (see Fig. 3 ) are the best approximation possible on the present evidence. The Carboniferous-Permian boundary is localized between Taphoflora $\mathrm{A}$ and the "transitional" one, i. e. about the middle part of the Itarare Subgroup.

Acknowlegments. I am especially grateful to Prof. W. G. CHALONER who offered valuable criticisms. Finance for field work was provided by Fapesp (Fundação de Amparo à Pesquisa do Estado de São Paulo - Brazil).

\section{BIBLIOGRAPHY}

BERNARDES-DE-OLIVEIRA, M.E.C. - 1977 - Tafoflora Eogondvânica da Camada Irapuá, Formação Rio Bonito (Grupo Tubarâo), SC. Doct. Thesis, Inst. Geociências - Univ. S. Paulo (unpublished). I: 301 pp., Vol. II: 38 pp., 36 pls.

DOLIANITI, E. \& MILLAN, J. H. - 1972 - Novo afloramento de vegetais gondwânicos no Estado de São Paulo. An. Acad. Bras. Ciencias, 45:653-654.

KRASSILOV, V. A. - 1969 - Types of palaeofloristics successions and their causes. Palaeontological Journ., 3 (1969): 269-308.

MILLAN, J. H. - 1972 - Macroflórula carbonífera de Monte Mor, Estado de São Paulo. Doct. Thesis. - Inst. Geosc., Univ. São Paulo, 154 pp., 12 pls.

MILlAN, J. H. - 1975 - Tafoflórula Monte Mor do Estado de São Paulo: Seus elementos e seu significado no Gondwana Inferior do Brasil. Revista Brasileira de Geociências. 5:1-14. (São Paulo).

RIGBY, J. F. - 1968 - New fossil locality near Laras, State of São Paulo. An. XXII Congr. Brasil. Geol. (B. (Horizonte, 1968): 201-208.

RIGBY, J. F. - 1970 - The distribution of Lower Gondwana plants in the Paraná Basin of Brasil. Proceed. Second Gondw. Symp. (Pretoria - 1970): 575-584.

RÖSLER, O. - 1973 - Tafofloras neopaleozóicas da Bacia do Paraná (Abstr.), Res. II Congr. Latinoamer. Geol. (Caracas - 1973): 32 . 
RÖSLER, O.

The Brazilian Eogondwanic Floral Succession p. 85 - 91

RÖSLER, O. - 1975a - Fossil Plants and the Problem of the Upper Limit of the Carboniferous System in the Brazilian Eogondwanic Sequence. (Abstr.), VIII Intern. Congr. Carbon. Strat. Geol., p. 234 (Moscow).

RÖSLER, O. - 1975b - The Brasilian Eogondwanic Floral Succession. (Abstr.), Palaeont. Assoc. Circ. (Open Meeting - Newcastle u. Tyne - 1975), 82a: 6.

RÖSLER, O. - in press - Novas ocorrências fossilíferas na Formação Rio do Rasto, Permiano Superior, Estado do Paraná. Bol. Inst. Geocienc. - this volume.

YOSHIDA, R. - 1970 - Novo gênero de conífera da Formação Estrada Nova, Norte do Estado de Santa Catarina. Bol. Div. Geol. Min..DNPM, 249:1-17, pl. 14. (Rio de Janeiro).

\title{
ENSAIO SOBRE A UTILIZAÇÃO DE CARACTERES BIOMÉTRICOS DAS GLOSSOPTERIDÓFITAS EM ESTRATIGRAFIA
}

\author{
MARY E. C. BERNARDES-DE-OLIVEIRA \\ (Instituto de Geociências - USP)
}

\section{ABSTRACT}

An evolutionary sequence of forms is proposed for the glossopteridophytes based on the morphographic characters of their leaves. Considering the average biometric properties of some of these characters, several "evolutionary indices" are proposed, that may be useful in eogondwanic biostratigraphy.

\section{INTRODUÇÃo}

Ao elaborar o Plano do Traité de Paléobotanique, Bou REAU (1967) introduziu na Sistemática Vegetal um novo taxon: Glossopteridophyta. O grande grupo de plantas eogondvânicas é caracterizado por vários tipos de folhas designadas pelos gêneros-formas Glossopteris, Gangamopteris, Palaeovittaria, Rubidgea; por numerosas frutificações a elas relacionadas, tais como: Ottokaria, Scutum, Lanceolatus, Hirsutum, Senotheca, etc., além de uma raiz ou rizoma (conforme SCHOPF, 1965 e GOULD, 1975) conhecida como Vertebraria.

Consideremos, por ora, apenas os gêneros-formas para folhas.

* Contribution to the PICG Project n? 42 Upper Paleozoic of South America. 